\title{
The use of EduBlog in initial teachers training: an experience of a teaching innovation project
}

\section{Isabel Pardo Baldoví, Diana Marín Suelves, M $^{\text {a }}$ Isabel Vidal Esteve}

CRIE Research Group, Department of Didàctica i Organització Escolar, Universitat de València, Spain.

\begin{abstract}
Digital technologies are central elements of today's society. In this context to achieve an adequate degree of development of Digital Competence for professional performance is essential, as well as for life in society and the exercise of citizenship. Higher Education must actively contribute to develop Digital Competence, training students to effectively use digital technologies. That need is exacerbated in the case of initial teacher training, not only because of the progress towards a digitalized school, but also because of the fundamental role in the training of future generations. With the aim of promoting the development of Digital Teaching Competence, this paper presents an innovation project implemented in the Degree of Teacher of Nursery and Primary Education of the University of Valencia that is based on the didactic use of EduBlog. The selection of this digital tool responds to its multiple benefits on the work of curricular content, the development of digital skills and the creation of a positive climate in the classroom. The project developed with a total of 131 second-year students demonstrates that the use of EduBlog has a positive impact on the learning process and on the increase in student engagement and motivation.
\end{abstract}

Keywords: Digital Competence; teacher education; higher education; EduBlog; student engagement; learning community. 


\section{Introduction}

In today's society, digital technologies play a fundamental role, since they are present in all their dimensions, from political and economic to the private sphere, so they have become elements of great importance in our daily lives (Castells, 2017). In this context, citizens need to be digitally competent to be able to perform their professions properly, to interact in the virtual framework and even to exercise active use of citizenship. Therefore, it is vital to offer an education capable of harnessing the potential of digital technologies, incorporating them as active elements of the student learning process (Area, 2019).

In this sense, it is essential to introduce digital technologies in Higher Education to enable students to exercise an effective and critical use of them, not only in their future professional development, but also in their daily lives (Pittinsky, 2006). This situation becomes even more important and necessary in the case of initial teacher training, because these will be responsible for training future generations in the development of Digital Competence (Marín, Vidal, Peirats \& San Martín, 2019). This phenomenon, together with the growing demand for the use of technological devices and digital platforms in nursery and primary education classrooms and the transformation of pedagogical work following the use of digital artifacts, require a training process that allows future teachers to use effectively the technologies and ponder about their use to apply them correctly with their students (Pardo, Waliño \& San Martín, 2018a). This need is reflected in the emergence of initiatives and regulations such as the Digital Agenda for Europe or the Strategic Framework: Education and Training 2020 (ET2020), and in the Spanish context the Agenda Digital para España and the Marco Común de Competencia Digital Docente designed by the Instituto Nacional de Tecnologías Educativas y de Formación del Profesorado (INTEF, 2017).

Achieving this objective is a challenge for teachers of Higher Education in general, and for the initial training of teachers in particular, since they must be concerned with offering training that links digital technologies with the vital reality of students, generating significant learning experiences that are not limited to the mere introduction of technologies, but that they affect the dynamic and live use of pampering, generating spaces for reflection and learning communities (Beetham \& Sharpe, 2013). Based on this scenario, we will now present an innovation experience developed in the Facultat de Magisteri of Universitat de València and that pursues the objective of facilitating the development of Digital Competence in future teachers through the use of EduBlog as a tool for learning.

\section{Using EduBlog as a tool for engage students in the learning process}

Currently, the catalog of artifacts and digital tools that can be incorporated into the classroom is very rich and varied, because technological development is growing at a dizzying pace (Bruillard, 2019). Therefore, one of the main issues that teachers must attend to is to properly 
select those digital resources that can contribute most to enrich the learning process of their students and, especially, that can facilitate the development of the Teaching Digital Competence, given the importance of it (Pardo, Waliño \& San Martín, 2018b).

Among the wide range of possibilities, in this experience the use of the Educational Blog or EduBlog as a didactic tool has been selected, given its potential to expand learning, motivate and favor the commitment of students in the process, in addition to energizing relationships in the classroom (Cabrera, 2019).

The EduBlog is an upward trend tool in Higher Education, especially in the initial training of teachers, due to the multiple benefits that its use can have in different spheres, both in relation to curricular contents, as well as to the development of digital skills and interpersonal relationships between those involved (Durán, 2010).

After the bibliographic study and the multiple advantages that recent research points to the use of EduBlog, it was decided to implement this resource based on the belief that using it in the university classrooms of initial teacher training allows the work in depth of the contents, favoring a positive attitude towards them and promoting reflection and critical analysis, by creating a learning community that manages to transcend the formal classroom scheme, taking root in the student's life and giving meaning to the contents (Marín \& Sampedro, 2016).

\section{The use of the EduBlog in initial teacher training: description of an experience}

With the objective of promoting the development of the Teaching Digital Competence in future teachers and preparing them for the correct exercise of their profession in the digital school (Waliño, Pardo \& San Martín, 2018), it was carried out during the 2018-2019 school year a teaching innovation project that starts from the use of EduBlog as a teaching tool.

\subsection{Participants}

An amount of 131 students of the second year of the Master's Degree in Nursery Education and Primary Education, of Special Education Needs subject of the University of Valencia, participated in this experience.

Table 1 shows the main characteristics of the students that compose each of the participating groups. 
Table 1. Participant Characteristics

\begin{tabular}{|c|c|c|c|c|}
\hline Variables & & Group D & Group H & Group 21R \\
\hline \multirow[t]{2}{*}{ Gender } & Man & $16 \%$ & $16 \%$ & $49 \%$ \\
\hline & Woman & $84 \%$ & $84 \%$ & $51 \%$ \\
\hline Age & Mode & 20 & 20 & 22 \\
\hline \multirow[t]{4}{*}{ Provenance } & Valencia & $39 \%$ & $60 \%$ & $36 \%$ \\
\hline & $\begin{array}{l}\text { Rest of Valencian } \\
\text { Community }\end{array}$ & $53 \%$ & $30 \%$ & $61 \%$ \\
\hline & Rest of Spain & $8 \%$ & $7 \%$ & $3 \%$ \\
\hline & Other Countries & - & $2 \%$ & - \\
\hline \multirow[t]{3}{*}{ Times enrolled } & Once & $100 \%$ & $98 \%$ & $15 \%$ \\
\hline & Twice & - & $2 \%$ & $59 \%$ \\
\hline & More than 2 times & - & - & $26 \%$ \\
\hline \multirow[t]{4}{*}{ Combined with a paid job } & No & $88 \%$ & $77 \%$ & $56 \%$ \\
\hline & Sporadic & $4 \%$ & $12 \%$ & $5 \%$ \\
\hline & Part Time & $6 \%$ & $12 \%$ & $31 \%$ \\
\hline & Full Time & $2 \%$ & - & $8 \%$ \\
\hline
\end{tabular}

Source: Own elaboration from university database.

\subsection{Process phases}

The project implementation process was developed in 6 different phases that covered the entire course and aimed at familiarization with the tool, the work and internalization of the contents and the generation of a learning community through EduBlog. The phases were as follows:

1. WordPress tool selection: After an informed search, WordPress was selected as the tool from which to build the EduBlog, given its ease of use.

2. Creation of the classroom blog: teachers created the blog and presented it to students, highlighting its benefits for the learning process.

3. Publication of entries: periodically published entries about the curricular contents that were being worked on in the subject, encouraging the active participation of students. 
4. Comments of the students: the students commented and provided feedback to the entries, reworking and reflecting on the contents worked in the classroom, which contributed to energizing the learning process lived.

5. Peer feedback: the information available in the EduBlog was growing progressively, facilitating the creation of a good classroom climate and enabling the generation of a true learning community that crossed the spatial and temporal barriers of the classroom, maximizing the benefits of learning.

6. Assessment of the experience: finally, after the application of the project, a space for reflective assessment by those involved, both students and teachers, was allocated. It was a formative evaluation aimed at making decisions for the improvement of the project in future applications.

These phases allowed the use of EduBlog to consolidate throughout the course and for students to see it as a tool with great potential for learning, increasing their commitment.

\section{Evaluation of the experience}

For the evaluation of the experience, three factors were taken into account. The first of them, the use of this tool during a four-month period. The second, the assessment of the experience by the participating students, and, finally, the third was the vision of the teachers involved.

Regarding the data that the application itself (WordPress) offers, the data referring to the number of visitors and tickets seen per month stand out.

Table 2. Number of visitors and entries

\begin{tabular}{ccccc}
\hline & February & March & April & May \\
\hline Num. Visitors & 257 & 154 & 78 & 145 \\
Num. Visits & 2812 & 898 & 1345 & 2004 \\
\hline
\end{tabular}

Source: Own elaboration from WordPress data

As for the countries from which EduBlog has been accessed, as can be seen in Figure 1, it highlights access from different countries, both Spanish-speaking and other languages, from countries geographically close to Spain and also distant. Especially from the American continent. 


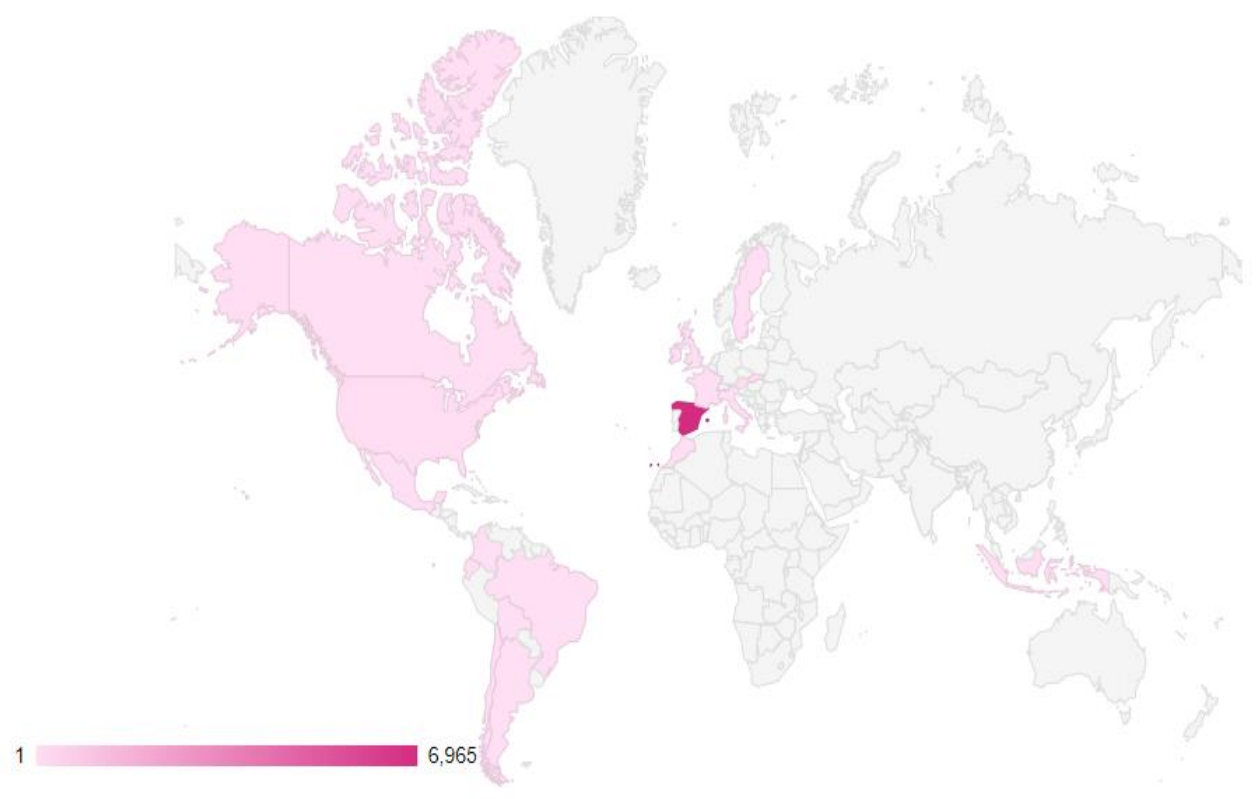

Figure 1. Distribution of visits per countries (15-05-2019)

Regarding the assessment of the experience carried out by the students, the information was collected through a questionnaire prepared ad hoc with the Google questionnaires tool. The link was sent to the participants through the News section of the Virtual Classroom of the subject. The positive assessment made stands out, with an average score of 8 '2. The positive aspects mentioned outweigh the negative aspects after the assessment of the introduction of this tool during a four-month period in Higher Education. They point out from EduBlog the possibility of sharing resources, which they can also use in their professional future, and the opportunities it offers to transmit information and learn about other points of view. As negative aspects, they point out the initial difficulty of using the tool and the repetition of comments. It is interesting that as proposals for improvement students highlight the need for easier access to the blog and that it was the student himself who made the proposals on which to deepen. The $80 \%$ of the participants would recommend its use in teacher training and the $60 \%$ had never made an educational use of this tool before.

Finally, teachers involved value the introduction of this tool very positively, because it has made possible the motivation of the students, the exchange of knowledge, the development of different competences, such as communicative and digital, the dissemination of knowledge beyond the limits of the classroom, the exchange of information with students from different groups and the promotion of the inclusive school, which is one of the fundamental objectives of the subject involved. 


\section{Conclusion}

As has been proven throughout the study, EduBlog is a tool that offers the opportunity to increase dialogic interactions between equals through a more relaxed and uninhibited space. And, in addition, its use favors sharing cultural, critical and diverse affinities around the issues that arise that, otherwise, in more conventional and formal environments, could go unnoticed. Therefore, as Cortés (2019) points out, collaborative learning and creativity development, promoting distance learning in which the research function and knowledge transfer are facilitated (Gonzalez-Hernando, Valdivieso \& Velasco, 2020). His pedagogical strengths are based on good teaching practices focused on students as a center of learning, in the line of constructivism by Jean Piaget and Lev Vygotsky. According to Marco Común de Competencia Digital Docente, it is structured in five main areas: information and information literacy, communication and collaboration, creation of digital content, security and problem solving (INTEF, 2017); and there is no doubt that the dynamics through EduBlog can favor all of them.

Although the technical solution proposed in this experience is not a novelty, because it is based on the use of a blog, the study have shown that this is a tool whose use is not yet widespread in classrooms of these degree. These aspects could be observed, specially, for the several difficulties presented in the handling of the blog by the students at the beginning of the experiencie. These show that, despite the fact that this student generation is usually considered "digital natives" they still need to develop certain aspects of digital competence, and especially of digital teaching competence. Objectives pursued in that learning experience.

Consistent with the methodological line of this work, it was tried to verify if the implementation of EduBlog in university classrooms of initial teacher training allowed the in-depth work of the contents and promoted their reflection and critical analysis. As the results obtained in the different phases show, the use of EduBlog was consolidated throughout the course until it was valued as a tool of great potential by both teachers and students. Even so, it would be interesting to take into consideration the proposals for improvement made by the students, among which are, to provide them with greater prominence, offering them the freedom of being the ones who created the proposals on which to deepen, instead of teachers.

Finally, it should be noted that one of the main limitations of this study, and that it would be interesting to solve in future research, is the size of the sample, as well as its development in such a limited context, that of a single subject -which, however, it is shared by future teachers of Nursery and Primary Education- for this reason, the results only correspond to an approximation of reality, and it is considered necessary to continue research in this line in order to provide the future body of teachers of the digital skills necessary for the society of 
the 21 st century. To achieve this goal, the next course will expand the experience to increase the sample size and to develop more meaningful experiences.

\section{Financing and acknowledgment}

To Conselleria de Educación, Investigación, Cultura y Deporte for the promotion of scientific research, technological development and innovation in Comunitat Valenciana. This paper is based on the results of phase I of project GV/2018/074.

To Ministerio de Ciencia, Innovación y Universidades by the grants to Formación del Profesorado Universitario (FPU16/04009 and FPU17/00372).

\section{References}

Area, M. (2019). Leadership and school integration of ICT. Teachers perceptions in Spain. Education and Information Technologies, 24(1), 549-565. doi: 10.1007/s10639-0189789-0

Beetham, H. \& Sharpe, R. (Eds.) (2013). Rethinking Pedagogy for a Digital Age: Designing for 21 st Century Learning. London: Routledge.

Bruillard, E. (2019). Enseigner à l'ère de l'internet: catalogues, couleurs et collections. Raison presente, 210(2), 37-49. doi: 10.3917/rpre.210.0037

Cabrera, C. E. (2019). El edublog en el contexto educativo universitario. Ciencia y Sociedad, 44(3), 7-23.

Castells, M. (2017). El panóptico digital. Vanguardia Dossier, 63, 74-77.

Cortés, L. C. (2019). El aprendizaje en línea. Una motivación. Revista iberoamericana de producción académica y gestión educativa, 6(11), 1-8.

Durán, J. F. (2010). La utilización del edublog en las aulas como dinamizador del proceso de enseñanza-aprendizaje. Docencia e Investigación: Revista de la Facultad de Educación de Toledo, 35(20), 205-243.

Gonzalez-Hernando, C., Valdivieso, L., y Velasco, V. (2020). Estudiantes universitarios descubren redes sociales y edublog como medio de aprendizaje. RIED. Revista Iberoamericana de Educación a Distancia, 23(1), pp. 223-239. doi: 10.5944/ried.23.1.24213

INTEF (2017). Marco común de competencia digital docente. Madrid: Ministerio de Educación. Retrieved from: goo.gl/7pvLve

Marín, V., Sampedro, B. E. (2016). Los edublogs como herramienta de trabajo en el aula de grado de educación primaria, Aula de Encuentro, 18(1), 109-128.

Marín, D., Vidal, M. I., Peirats, J., \& San Martín, Á. (2019). Competencia digital transversal en la formación del profesorado, análisis de una experiencia. Innoeduca: International Journal of Technology and Educational Innovation, 5(1), pp. 4-12. 
Pardo, M. I., Waliño, M. J., \& San Martín, Á. (2018a). La 'uberización' de los centros escolares: reorganización del trabajo pedagógico mediante las plataformas digitales de contenidos. Educatio siglo XXI, 36(2), 187-208. doi: 10.6018/j/333031

Pardo, M. I., Waliño, M. J., \& San Martín, Á. (2018b). La competencia digital docente: análisis del plan de estudios del Máster de Profesorado de Educación Secundaria de la Universistat de València. XXVI edición de las Jornadas Universitarias de Tecnología Educativa (JUTE2018), 243-248.

Pittinsky, M. (Ed.) (2006). La universidad conectada. Perspectivas del impacto de Internet en la educación superior. Málaga: Aljibe.

Waliño, M. J., Pardo, M. I., \& San Martín, Á. (2018). Formación del profesorado para la ciudadanía digital. XXVI edición de las Jornadas Universitarias de Tecnología Educativa (JUTE2018), 318-323. 